\title{
カオス性の異なる1/fゆらぎを用いた拍手のアニメーションの感性評価
}

\author{
山田 光宏, 井上 裕貴, 野月 悠平, 大和田 祥平, 金沢 文恵, 中村 雅人 \\ 茨城大学工学部
}

\section{KANSEI Evaluation of Hand-Clapping Animation Utilizing 1/f Fluctuations with Different Chaotic Properties}

\author{
Mitsuhiro YAMADA, Hiroki INOUE, Yuuhei NOZUKI, Sho-hei OHWADA, \\ Fumie KANEZAWA and Masato NAKAMURA
}

College of Engineering, Ibaraki University, 4-12-1 Nakanarusawa, Hitachi-shi, Ibaraki 316-8511, Japan

\begin{abstract}
In various human motions, $1 / f^{\beta}$ fluctuation has been observed, so that $1 / f$ fluctuation has been utilized for producing human animation in order to make it more human-like and natural. The $1 / f$ fluctuation has been also utilized for producing animation of natural scenes, control of artificial environment, or etc., in order to make them more natural. Chaotic $1 / f$ fluctuation or non-chaotic one has been utilized, however, subjective comparison between them has not been studied yet. In this paper, hand-clapping animation utilizing them is investigated by subjective comparison. As a result, the case with chaotic $1 / f$ fluctuation was more natural and human-like than the case with non-chaotic one.
\end{abstract}

Keywords : Kansei evaluation, $1 / f$ fluctuation, Human animation

\section{1.はじめに}

近年, 映画やゲームなどのエンターテインメントの分野な どに挄て、コンピュータグラフィックス $(\mathrm{CG})$ により人工 的に人体すなわち $\mathrm{CG}$ キャラクタと, その動作を生成した動 画映像が制作されることが多くなってきている，実写と同等 のリアルな人間の動作を表現するCGアニメーション（以下 「ヒューマンアニメーション」とする) を制作するためには, 人体の形状だけでなく, 自然な, 人間らしい動作を再現する 必要がある，人間の様々な動作においては，時間的に変化す る $1 / f^{\beta}$ ゆらぎがみられる。ここで， $f$ は周波数であり，時系 列のパワースペクトル密度 $P(f)$ が $f$ に対して低周波領域にお いて $P(f) \propto 1 / f^{\beta}$ となるゆらぎを $1 / f^{\beta} ゆ ら き ゙ と$ 呼び, 指数 $\beta$ が

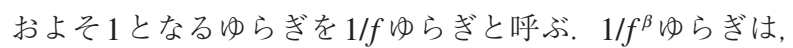
拍手の動作 [1] や, 指を動かすタッピング [2], マウスを動 かす際の手の動き [3]にみられることが報告されている. このように, 人間の動作は, 単に規則的, 周期的なものでは なく、ゆらぎを伴うものであり, ゆらぎが人間らしさの重要 な要素であると考えられる

そこで, 先行研究 [4]では, より自然で, 人間らしいヒュー マンアニメーションを実現するため, 逆運動学 [5]を用いて $\mathrm{CG}$ キャラクタの動作を生成する手法において, 単一の $\mathrm{CG}$

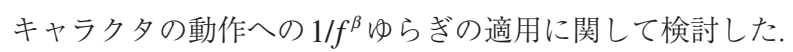
逆運動学を用いた手法は, コストの高いモーションキャプ チャや手作業によらずにCGキャラクタの動作を生成可能な 手法である，CGキャラク夕の動作としては，前述したよう

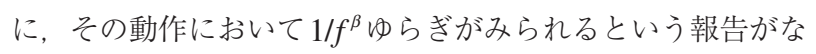

されている拍手の動作を採り上げた。感性評価実験により心 理的評価に関して検討した結果，拍手の周期および振幅を一 定とした場合に比較し，周期を一定とし振幅のみに $\beta$ を 1 と

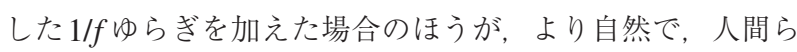
しいものであった.

$1 / f^{\beta}$ ゆらぎにおける指数 $\beta$ は時系列の乱雑さを定量化する ものとなるが $[6]$, 一方で, 定量化にフラクタル次元を取り 込んだGrassbergerらの提案する相関次元推定法 [7] があ り，カオス性の有無を検定する標準的なアルゴリズムとし

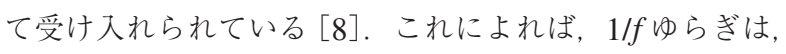

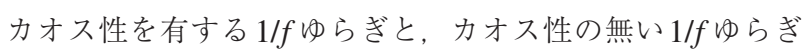
に明確に区別される.

カオス性を有する $1 / f$ ゆらきに関しては，比較的簡単な

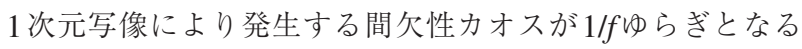
ことから,これが人工環境の温度の制御 [9] や照明の制御 [10］ に適用され，心理的評価により快適性の向上効果が認められ ている。 ここで, 間欠性カオスとは, 定常状態と不規則な状 態が間欠的に発生するようなカオスである. 以下, 間欠性力 オスによるカオス性を有する $1 / f$ ゆらぎを「カオス的な $1 / f$

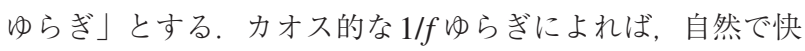
適な人工環境の創造を可能にするものと考えられ， $\mathrm{CG}$ キャ ラクタの動作に適用した場合, 自然なヒューマンアニメー ションを実現する可能性があると考えられる。

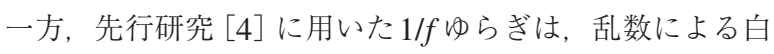
色雑音を $1 / f$ 型の周波数特性を有するデイジタルフィル夕に 通すことにより発生させたものであり, カオス性の無い $1 / f$

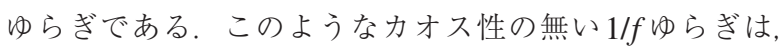

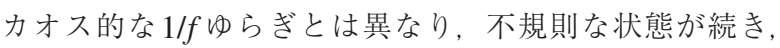


定常状態になることは無い. 以下, カオス性の無い $1 / f$ ゆら ぎを「カオス的でない $1 / f$ ゆゔ」とする，前述したように，

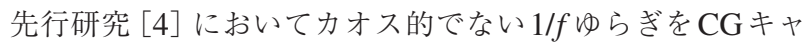
ラクタの動作に適用した場合, 自然な, 人間らしいヒューマ ンアニメーションを実現した。

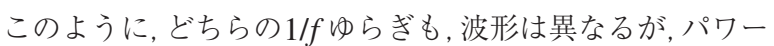
スペクトルは同じ $1 / f$ 型であり, 従来, 自然で人間らしい ヒューマンアニメーションの制作や, 自然で快適な人工環境 の創造などに用いられてきた。しかしながら，従来は，自然 さ，人間らしさ，快適さなどと $\beta$ の值との関連のみが注目さ れており, 自然さ, 人間らしさ, 快適さなどとカオス性の有 無との関連に関する感性評価による検討はなされていない。

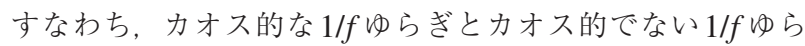
ぎの心理的評価に関する比較検討は行われていない.

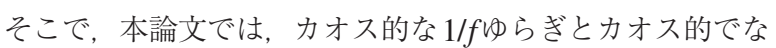
い $1 / f$ ゆぎを拍手のアニメーションに用いて, 感性評価実 験により心理的評価に関する比較検討を行うことにより，ど ちらの1/fゆらぎがより自然で人間らしいヒューマンアニメー ションを実現するか明らかにすることを目的とする [11, 12]. 先行研究 [4] に基づき, 拍手の周期を一定とし拍手の振幅 のみに $1 / f$ ゆゔを加えることとし, 先行研究と同様にアニ メーションの制作および感性評価実験を行う。なお, 本論文 はCGキャラク夕の動作に関する検討であり, ゆらぎの映像 における効果のみを検討するため, 先行研究 [4] と同様に 拍手音は発生させず，音による影響を除いた音を伴わない アニメーションを扱う。本論文では, ゆらぎの効果が被験者 にとり，より明確になるよう，まず，画面内に大きく映し出 された単一の $\mathrm{CG}$ キャラクタによるアニメーションにおい て，カオス的な $1 / f$ ゆらきを用いた場合とカオス的でない $1 / f$ ゆらぎを用いた場合の比較検討を行う。単一の CGキャラク 夕による検討は先行研究 [4]に拈いても行ったが, 一般的 なヒューマンアニメーションにおいては, 画面内に複数の CGキャラクタが用いられる場合が多いと考えられる。この

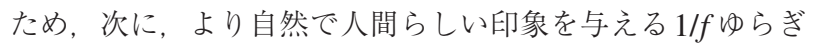
を複数のCGキャラク夕による拍手のアニメーションに用い る.そして, $1 / f$ ゆらぎを用いない場合と比較し, 一般的な ヒューマンアニメーションと同様な場合における自然さ,

人間らしさに関する有効性を感性評価により検討する.

以下，2章で関連研究について述べた後，3章では $1 / f$ ゆら ぎ時系列の発生方法とカオス性の有無の確認のための検定に 関して述べる，4章では，単一の CGキャラク夕による拍手

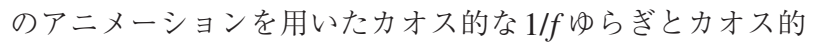
でない $1 / f$ ゆらざの比較検討に関して，5章では，複数のキャ ラクタによる拍手のアニメーションを用いた検討に関して述 ベる．6章では結論を述べる

\section{2. 関 連 研 究}

ヒューマンアニメーションの制作において，コストの高い モーションキャプチャや手作業によらずにCGキャラクタの
動作を生成可能な手法としては, 逆運動学や力学シミュレー ションを用いた手法がある。 そのような手法として, 力学シ ミュレーションに基づき人物歩行のアニメーションを自動生 成する手法 [13］や，神経振動子を用いた，より少ない計 算コストで歩行アニメーションを生成する手法 [14]，倒立 振子という比較的単純な物理モデルと逆運動学により人間の バランス保持動作を実現する手法 [15] などが提案されてい る。しかしながら, それらは力学的, 運動学的に妥当な人間 の動作を実現するのみであり，ゆらぎを考慮していない，逆

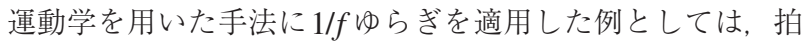
手のアニメーションにカオス的でない $1 / f$ ゆゔを適用した 先行研究 [4] がある.

ヒューマンアニメーション以外に, 様々な自然現象において $1 / f^{\beta}$ ゆらざがみられるため $[16]$, 自然景観を表現するCGア ニメーションの制作に $1 / f^{\beta}$ ゆらきを適用した例もある。その 制作において, 力学シミュレーションに基づく手法では計算

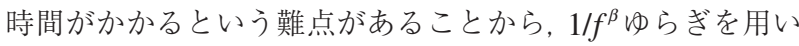
た，風による自然な木の枝や葉の動きのアニメーション [17] や，滝の流れにおいて特徵的である本流，飛沫，水煙，波を $1 / f^{\beta}$ ゆらぎを用いて効率的に表現する滝のアニメーション生 成法 [18] が提案されている. また, 風になびくカーテンや, ろうそくの炎による光のゆらぎ，水に沈んだ写真のCGによ る表現に $1 / f$ ゆゔを適用する手法も提案されている [19]

アニメーション以外にも, 従来, 自然で快適な人工環境を

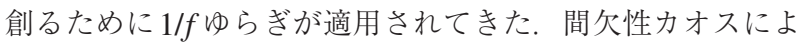

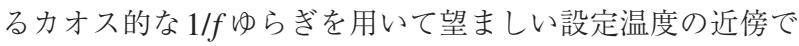
の温度ゆらぎを実現した石油ファンヒータが作られ，心理的 評価により，ゆらぎによる快適性の向上が確認された例があ る [9]．また，癒しを与える空間の創生のため，照明光を間

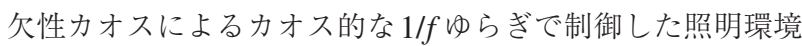
を構築し, 心理的評価により快感情の向上効果が認められ, また，生理学的検証により $\alpha$ 波の増加が認められた例があ

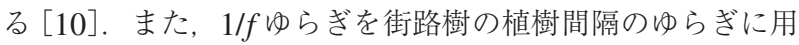
いた場合の快適性について検討した例もある [20].

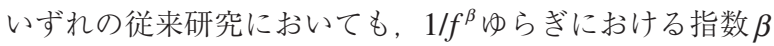
の值と自然さ，人間らしさ，快適さなどとの関連についての みが注目されており, カオス性の有無と自然さ, 人間らしさ, 快適さなどとの関連に関する感性評価による検討は行われて

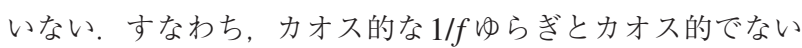
$1 / f ゆ ら き ゙ の 心$ 理的評価に関する比較検討は行われていない.

\section{3. $1 / f$ ゆらぎ時系列の発生とカオス性の検定}

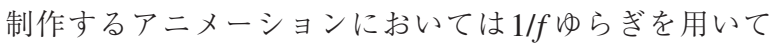
1 回毎の拍手の振幅を変化させるため, 拍手の回数が, ア二 メーションの制作に必要な $1 / f ゆ ら き ゙$ 時系列の長さとなる. 時系列のスペクトル解析にFFTを用いるため拍手の回数を 2のべき乗とし,また, 拍手の回数を535回とした先行研究 [4] と大きく異ならないようにするため, 本論文では拍手の回 数を 512 回とした。したがって，アニメーションの制作に 
必要な時系列の長さは 512 となる。前述したように拍手の 周期は一定とし, 先行研究 [4] と同様に拍手音の周期の測 定結果 [21] に基づき 0.28 秒とした. このため,アニメーショ ンの制作に用いる時系列の標本化周期は 0.28 秒であり, その逆数である $3.57 \mathrm{~Hz}$ が標本化周波数となる.

まず，カオス的な $1 / f$ ゆらぎの時系 $d_{C}(n)$ の発生方法に関 して述べる.ここで, $n$ は離散時間である. $d_{C}(n)$ の発生には, 次式に示す一次元変形ベルヌーイ写像 $g\left(d_{C}\right)\left(0 \leq d_{C} \leq 1\right)$ によ る間欠性カオスを用いた [22].

$$
\begin{aligned}
& d_{C}(n+1)=g\left(d_{C}(n)\right) \\
& \quad= \begin{cases}d_{C}(n)+2^{B-1}(1-2 \varepsilon)\left(d_{C}(n)\right)^{B}+\varepsilon, & \left(0 \leq d_{C}(n) \leq \frac{1}{2}\right) \\
d_{C}(n)-2^{B-1}(1-2 \varepsilon)\left(1-d_{C}(n)\right)^{B}-\varepsilon, & \left(\frac{1}{2}<d_{C}(n) \leq 1\right)\end{cases}
\end{aligned}
$$

ここで, 小摂動 $\varepsilon(>0)$ は $1 \times 10^{-13}$ とした, 式 (1)により発生さ れる時系列は $1 / f^{\beta}$ ゆらぎとなり, $1 / f^{\beta}$ ゆらぎの指数 $\beta$ と式 (1) に扮ける非負の分岐パラメータ $B$ の関係が $\beta \cong 3-B /(B-1)$ で 与えられるとされている [22].ここでは， $\beta \cong 1$ となるよう $B=2$ とした.

次に, カオス的でない $1 / f$ ゆゔ時系列 $d_{N}(n)$ の発生方法 に関して述べる。 $d_{N}(n)$ の発生には, 次式に示すような, 乱 数による白色雑音 $I(n)$ を用いた, $1 / f^{\beta}$ 型のスペクトルが得ら れるインパルス応答 $h(l)$ を有するディジタルフィルタによる 畳込み演算を適用した [23].

$$
\begin{aligned}
& h(l)= \begin{cases}1, & (l=0) \\
\prod_{k=1}^{l} \frac{\beta_{0} / 2+k-1}{k}, & (l \geq 1)\end{cases} \\
& d_{N}(n)=\sum_{l=0}^{L-1} h(l) I(n-l)
\end{aligned}
$$

ここで, 式 (2) における $\beta_{0}$ が $1 / f^{\beta}$ ゆらぎの指数 $\beta$ となると されているため [23], ここでは $\beta_{0}$ を 1 とた。 また, 式 (3) の $L$ はインパルス応答長であり, $1 / f$ ゆざの周波数成分の 最低周波数が標本化周波数の $1 / L$ となり，L回の拍手にわた る周期が $1 / f$ ゆぎとなる最長周期となる．Lは前述した拍 手の回数にあわせて 512 とした。

発生した時系列のカオス性の有無の確認のため, Grassbergerらの相関次元推定法によるカオス性の検定を行っ た. 検定のためには十分長い時系列が必要となるため, $d_{C}(n)$ および $d_{N}(n)$ を, それぞれ, $1 \times 10^{7}$ の長さの時系列として 求めた. 検定においては, 次式による相関積分を求めた [24].

$$
C^{m}(r)=\sum_{i \neq i} H\left(r-\left\|\vec{w}_{i}-\vec{z}_{j}\right\|\right)
$$

ここで, $H(u)$ はへビサイド関数で, $u \geq 0$ のとき $1, u<0$ のと き0である. また, $\vec{w}_{t}$ は, 埋め込みにより時系列 $d(i)$ を $m$ 次元 のベクトル $(d(i), d(i+1), \cdots, d(i+m-1))$ としたものであり, $\vec{z}_{j}$ もまた同様に $m$ 次元のベクトル $(d(j), d(j+1), \cdots, d(j+m-1))$ で ある. $\left\|\vec{w}_{i}-\vec{z}_{j}\right\|$ は $\vec{w}_{i}$ と $\vec{z}_{j}$ の距離である. $r$ は距離を表す変数であ り, $C^{m}(r)$ は 2 つべクトルの距離の累積分布関数となる.
$C^{m}(r)$ が次式のようにスケーリングされるような $r$ 領域に おいて,

$$
C^{m}(r) \propto r^{v(m)}
$$

相関指数 $v(m)$ が埋め込み次元 $m$ によらず一定となるとき, カ オス的な時系列と判定される．ここで， $r$ の領域 $r_{0} \leq r \leq\left(r_{0}+\Delta r\right)$ に拈いて $C^{m}(r)$ が式 (5) のようにスケーリングされるとす る。このとき， $c_{0}$ を定数とすると，

$$
\begin{aligned}
& C^{m}\left(r_{0}\right)=c_{0} \cdot r_{0}^{v(m)} \\
& C^{m}\left(r_{0}+\Delta r\right)=c_{0} \cdot\left(r_{0}+\Delta r\right)^{v(m)}
\end{aligned}
$$

となるので, 式 (6) および式 (7) の両辺の対数をとること により,

$$
\begin{aligned}
& \log _{10} C^{m}\left(r_{0}\right)=v(m) \log _{10} r_{0}+\log _{10} c_{0} \\
& \log _{10} C^{m}\left(r_{0}+\Delta r\right)=v(m) \log _{10}\left(r_{0}+\Delta r\right)+\log _{10} c_{0}
\end{aligned}
$$

となる. 式 (9) から式（8）を, 辺々, 差し引いて整理すると, 次式により $v(m)$ が与えられる。

$$
v(m)=\frac{\log _{10} C^{m}\left(r_{0}+\Delta r\right)-\log _{10} C^{m}\left(r_{0}\right)}{\log _{10}\left(r_{0}+\Delta r\right)-\log _{10} r_{0}}
$$

$d_{C}(n)$ および $d_{N}(n)$ に関して, それぞれ, 式 $(10)$ における $\log _{10} r_{0}$ を 3 つ定めることにより $r$ の領域を 3 つ定めたときの $v(m)$ の近似值を図 1 に示す. $\log _{10} r_{0}$ の值は図中に示す。ここで, $\Delta r$ は, 適切に $v(m)$ が近似されるよう試行錯誤により式(10) の分母が $1.50 \times 10^{-1}$ となるように定めた．2つの時系列には 定性的な違いが明確にみられる。 $d_{C}(n)$ の場合は $m$ および $r$ の 領域の定め方によらず $v(m)$ が一定となり，カオス的な時系 列と判定される。一方， $d_{N}(n)$ の場合は $r$ の領域の定め方によ らず $m$ に比例して $v(m)$ が増加しており，カオス的でない時 系列と判定される。よって, $d_{C}(n)$ がカオス的な時系列であ り， $d_{N}(n)$ がカオス的でない時系列であることを確認した。

アニメーションの制作に必要な時系列の長さは512である ため, $1 \times 10^{7}$ の長さの時系列 $d_{C}(n)$ および $d_{N}(n)$ から長さ 512 の部分を取り出し, 平均 0 , 分散 1 に規格化した時系列を, それぞれ， $D_{C}(n)$ および $D_{N}(n)$ とした。 $D_{C}(n)$ および $D_{N}(n)$ を 眓 2 に, それらのパワースペクトルを図3に示す。間欠性力 オスは定常状態と不規則な状態が間欠的に発生するカオスで あるが，その特徴が図2（a）に現れている。一方，図2(b)に

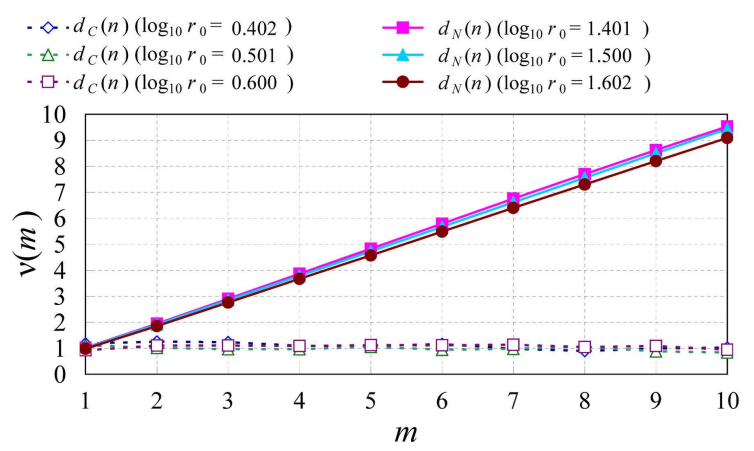

図1 埋め込み次元 $m$ に対する相関指数 $v(m)$. 


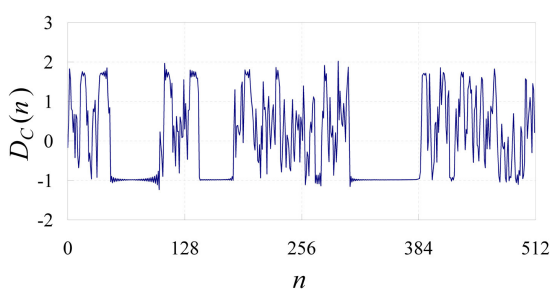

(a)

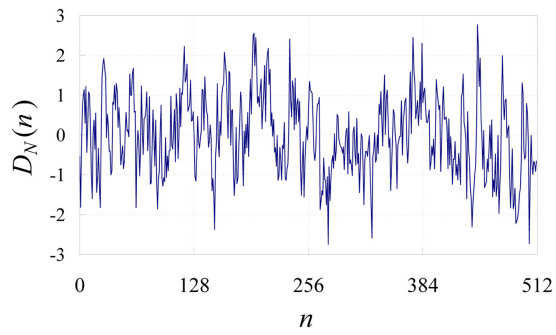

(b)

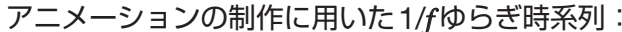

(a) $D_{C}(n)$, (b) $D_{N}(n)$

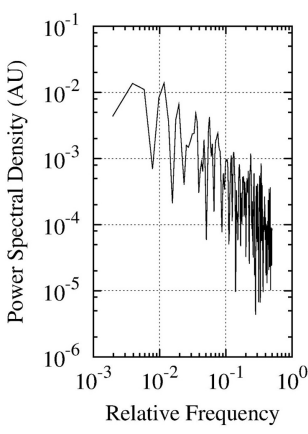

(b)

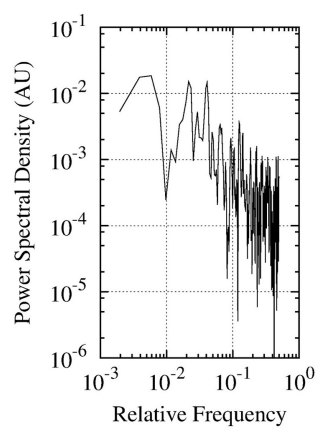

(b)
図3 パワースペクトル : (a) $D_{C}(n)$ の場合 $(\beta=1.04)$,

(b) $D_{N}(n)$ の場合 $(\beta=1.06)$.

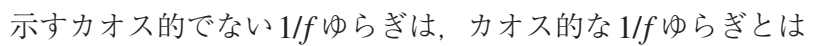
異なり不規則な状態が続き定常状態になることが無く, 2 つ の波形は異なっている. 図3の横軸は標本化周波数 $(3.57 \mathrm{~Hz})$ を1としたときの相対周波数 (Relative Frequency) を表し, 縦軸はパワースペクトル密度 (Power Spectral Density) を表す. 波形は異なるが, どちらもパワースペクトルは $1 / f^{\beta}$ 型である. 相対周波数 $4.80 \times 10^{-1}$ 以下の範囲で最小二乗法によりパワー スペクトル密度を直線近似し指数 $\beta$ を求めたところ, $D_{C}(n)$ および $D_{N}(n)$ において，それぞれ，1.04抢よび1.06と，ほぼ

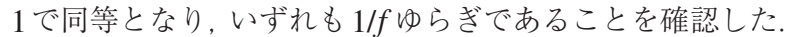

\section{4. 単一のCGキャラクタによるカオス性の異なる $1 / f$ ゆらぎを用いた拍手のアニメーションに関する検討}

\section{1 アニメーションの制作}

アニメーションの制作は先行研究 [4] と同様に行った. 拍手の周期が 0.28 秒で一定であり, 拍手の回数が 512 回であ るため, 143秒間のアニメーションを制作することになる. 人間の両肩を結ぶ線分の中点を原点 $O(0,0,0)$ とし肩幅を長さ の基準1とする図4に示す座標系を用いて, POV-Ray [25]
によるレンダリングを行い，アニメーションの要素であるフ レームとなる図 5 に示すような画像を制作した。制作した動 画映像は 1 秒間に60フレームとした。 $C G$ フャラクタの肩幅 以外の各部の大きさは, 18 才以上 30 才未満の男子の体の平 均值 [26］に基づき肩幅を 1 とした相対值として設定し, 可動 となる関節を手首，肘，肩の3つとした，左手首拉よび右手 首の中心の $y$ 座標および $z$ 座標は試行錯誤により決定した適 切な值で一定とし, 両手首の中心の $x$ 座標のみを変化させ ることにより拍手の動作を実現した．左手首および右手首の 中心の $y$ 座標は, それぞれ, $-6.86 \times 10^{-1}$ および-6.31× $10^{-1}$ とし，両手首の中心の $z$ 座標は $-2.75 \times 10^{-1}$ とした，左肩お よび右肩の座標は，眓4に示すように，それぞれ，(0.5,0,0) および $(-0.5,0,0)$ で一定とした。両肘の座標は, 逆運動学 [5] により, 運動学的に妥当な動作となるように決定した. $n$ 回目 の拍手の開始時点からの経過時間を $t_{n}\left(0 \leq t_{n}<0.28\right)$ 秒とすると き, $n$ 回目の拍手に打ける左手首および右手首の中心の $x$ 座 標を，それぞれ， $x_{L}\left(t_{n}\right)$ 拉よび $x_{R}\left(t_{n}\right)$ とし，次式で与えた。

$$
x_{L}\left(t_{n}\right)=-x_{R}\left(t_{n}\right)= \begin{cases}s\left(t_{n}\right) & \text { for } s\left(t_{n}\right) \geq C_{g} \\ C_{g} & \text { for } s\left(t_{n}\right)<C_{g}\end{cases}
$$

ここで， $C_{g}$ は手のひらの厚みの半分の值である $4.42 \times 10^{-2}$ とした， $x_{L}\left(t_{n}\right)$ の值が $C_{g}$ となるとき図 $5(\mathrm{a})$ に示す手のひら が合わさる状態となる。また, $s\left(t_{n}\right)$ は先行研究 [4] と同様に 次式で与えられる正弦波とした。

$$
s\left(t_{n}\right)=\frac{A(n)}{4}\left\{\sin \left(2 \pi \frac{t_{n}}{0.28}-\frac{\pi}{2}\right)+1\right\}
$$

ここで, $A(n)$ は $n$ 回目の拍手における $x_{L}\left(t_{n}\right)$ と $x_{R}\left(t_{n}\right)$ の最大間 隔，すなわち拍手の振幅である。 $A(n)$ には次式によりゆら ぎを加え, ゆらぎの大きさが先行研究 [4]に基づく最適值

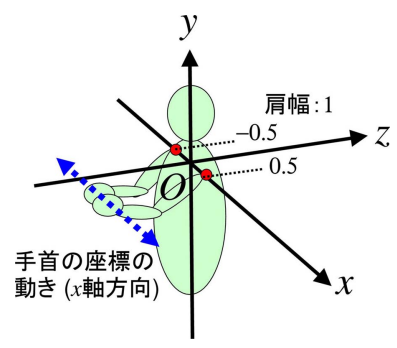

図4 単一のCGキャラクタによるアニメーションの 制作に用いた座標系.

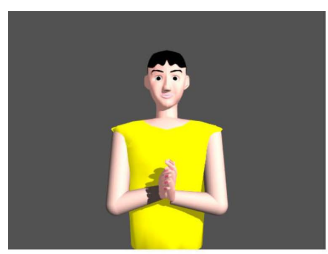

(b) (b)

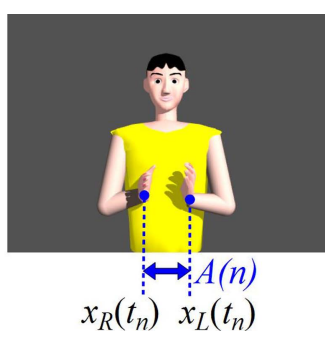

図5 単一のCGキャラクタによるフレームの例 : (a) 拍手を開 始するとき, (b) $x_{L}\left(t_{n}\right)$ と $x_{R}\left(t_{n}\right)$ の間隔が最大值 $A(n)$ となるとき. 
となるようにし, $A(n)$ の平均值も先行研究 [4] と同様に肩 幅の半分すなわち 0.5 となるようにした。

$$
A(n)=0.5\left\{1+\frac{10.6}{100} \times D(n)\right\}
$$

式 (13)の $D(n)$ に $D_{C}(n)$ もしくは $D_{N}(n)$ を用いることにより, カオス的な $1 / f$ ゆらぎを用いたアニメーション $A_{C}$ およびカオ ス的でない $1 / f$ ゆざを用いたアニメーション $A_{N}$ を制作した。

\section{2 感性評価実験の方法}

感性評価実験は自然さ，人間らしさに関して比較検討する ためのものだが, 自然さ, 人間らしさの評価に最適な質問項 目はあらかじめわからない。このため, 感性評価実験には, 先行研究 [4] と同様に,「不自然な一自然な」,「人間らしく ないー人間らしい」などを含む，ヒューマンアニメーション の評価に適切と考えられる多様な19種類の形容詞対により 構成されたSD 法による図6に示す感性評価票を用いた。そ して，因子分析を用いて最適な質問項目すなわち形容詞対を 抽出し比較検討することとした。 また, 被験者が評価しやす いように比較的段階の数の少ない 5 段階評定尺度法を用い, 評価の值を 2 からー2までとした. 評価は, 一方のアニメーショ ンに比較して他方のアニメーションをどのように評価する かという， 2 種類のアニメーションの間での相対評価とし, 被験者にはその旨説明した. また, 提示しているアニメーショ ンが $A_{N}$ と $A_{C}$ のどちらであるかについては伏せ，ブラインド テストとした。被験者は 19 歳から 24 歳までの男性33名で あった。アニメーションの提示には23インチの液晶ディス プレイを用い，画面から約 $1 \mathrm{~m}$ 離れた位置に被験者を着席さ せた。各被験者に対する実験は次の手順で行った。最初に $A_{N}$ と $A_{C}$ を同時に提示しながら実験に関する説明を行った 次に $A_{N}$ のみを提示し, $A_{N}$ につての感性評価票の各形容詞 対についてー2から 2 までの評価の欄のいずれかに印を記入 させた，次に $A_{C}$ のみを提示し， $A_{C}$ についての感性評価票に

\begin{tabular}{|c|c|c|c|c|c|c|}
\hline & 2 & 1 & 0 & -1 & -2 & \\
\hline 飽きのくる & & & & & & 飽きのこない \\
\hline アクティブな & & & & & & アクティブでない \\
\hline 生き生きしていない & & & & & & 生き生きした \\
\hline 印象的でない & & & & & & 印象的な \\
\hline 違和感のない & & & & & & 違和感のある \\
\hline おもしろい & & & & & & つまらない \\
\hline おもちやつぽい & & & & & & 本物っぽい \\
\hline 重々しい: & & & & & & 軽やかな \\
\hline 機械的な & & & & & & 機械的でない \\
\hline 元気一杯な: & & & & & & 元気のない \\
\hline 心地わるい: & & & & & & 心地よい \\
\hline 不自然な & & & & & & 自然な \\
\hline 親しみやすい & & & & & & 親しみにくい \\
\hline 好きでない & & & & & & 好きな \\
\hline 単調な: & & & & & & 複雑な \\
\hline 滑らかな & & & & & & 滑らかでない \\
\hline 人間らしくない & & & & & & 人間らしい \\
\hline メリハリのある: & & & & & & メリハリのない \\
\hline ありふれた & & & & & & めずらしい \\
\hline
\end{tabular}

図6 感性評価票.
$A_{N}$ と同様に記入させた。最後に $A_{N}$ および $A_{C}$ を同時に提示 し，任意の時間，必要に応じて評価を修正させた，以上によ り，被験者 1 人あたり 2 通りの感性評価が得られた

\section{3 感性評価実験の結果およびその分析}

得られた評価に対して因子分析を適用した。因子の抽出に は主因子法を用いた。固有值 1 以上の次元で因子の数を 3 と 決定し，バリマックス回転を行い，表1に示す因子負荷量を 得た。ただし，形容詞対の欄には，図6に示す評価がー（マイ ナス）側の形容詞のみ示している. 第1因子においては, 「不自然な一自然な」「人間らしくない一人間らしい」など に対して因子負荷量が高く，「自然さ・人間らしさ」に関す る因子とした。第 1 因子に関わる形容詞対が「自然さ・人間 らしさ」の評価に最適な形容詞対と考えられ，それらに特に 注目することとした．

次に，全ての形容詞対についての33名の被験者による評 価の平均值を, $A_{C}$ と $A_{N}$ の2通りについて, それぞれ求めた。 それらの平均值を, 以降, 被験者間平均值と呼ぶこととする. 2 通りの被験者間平均値の間での有意差の有無について, $\mathrm{t}$ 検定を用い，有意水準を $5 \%$ として検定した，表2に，各形 容詞対の被験者間平均值と $p$ 值を示す。

まず，第 1 因子の「自然さ・人間らしさ」に関わる形容詞 対について検討する，例えば，「不自然なー自然な」に関し ては, $p$ 值が 0.027 と有意水準より小さいため $A_{C}$ の被験者間 平均值 -0.273 と $A_{N}$ の被験者間平均值 0.697 との間で有意差 があるといえる，また，被験者間平均值の正負の符号を考慮 すると，「自然な」の側すなわちマイナスの值である $A_{C}$ のほ うが，「不自然な」の側すなわちプラスの值である $A_{N}$ に比較 し，より自然なものであったといえる。同様に，第 1 因子と なる「自然さ・人間らしさ」に関する因子の他の 5 つの有意 差のある形容詞対も $A_{N}$ に比較して $A_{C}$ のほうが肯定的な結果

表1 因子と因子負荷量.

\begin{tabular}{|l|r|r|r|r|}
\hline 形容詞対 & \multirow{2}{*}{ マイナス側のみ) } & 子 & \multicolumn{3}{|c|}{ 因子負荷量 } \\
\cline { 3 - 5 } & & 第1因子 & 第2因子 & 第3因子 \\
\hline \hline 自然な & 1 & 0.858 & -0.207 & 0.020 \\
\hline 本物っぽい & 1 & 0.854 & -0.296 & 0.090 \\
\hline 機械的でない & 1 & 0.812 & -0.220 & 0.011 \\
\hline 心地よい & 1 & 0.762 & -0.233 & 0.033 \\
\hline 人間らしい & 1 & 0.737 & -0.338 & 0.144 \\
\hline 違和感のある & 1 & -0.690 & -0.064 & -0.183 \\
\hline 生き生きした & 1 & 0.617 & -0.384 & -0.245 \\
\hline 親しみにくい & 1 & -0.599 & 0.208 & 0.167 \\
\hline 軽やかな & 1 & 0.595 & -0.053 & -0.070 \\
\hline 飽きのこない & 1 & 0.582 & -0.509 & 0.023 \\
\hline \hline メリハリのない & 2 & -0.095 & 0.754 & -0.034 \\
\hline 元気のない & 2 & -0.132 & 0.646 & 0.249 \\
\hline 複雑な & 2 & 0.458 & -0.592 & -0.158 \\
\hline つまらない & 2 & -0.327 & 0.488 & 0.384 \\
\hline 好きな & 2 & 0.423 & -0.437 & 0.258 \\
\hline 印象的な & 2 & 0.084 & -0.424 & -0.163 \\
\hline \hline アクテイブでない & 3 & -0.167 & 0.381 & 0.597 \\
\hline めずらしい & 3 & -0.058 & -0.128 & -0.541 \\
\hline 滑らかでない & 3 & -0.340 & 0.086 & -0.427 \\
\hline \hline \multicolumn{1}{|c|}{ 因子寄与率 } & & 0.307 & 0.154 & 0.069 \\
\hline 累積寄与率 & & 0.307 & 0.460 & 0.530 \\
\hline
\end{tabular}


表2 各形容詞対における被験者間平均値および $p$ 值 (*が付されたものが有意差のある形容詞対).

\begin{tabular}{|c|c|c|c|c|}
\hline \multirow{2}{*}{$\begin{array}{l}\text { 形容詞対 } \\
\text { (プラス側 -マイナス側) }\end{array}$} & \multirow{2}{*}{ 因 } & \multicolumn{2}{|c|}{ 被験者間平均值 } & \multirow{2}{*}{$p$ 值 } \\
\hline & & $A_{C}$ & $A_{N}$ & \\
\hline 不自然なー自然な & 1 & -0.273 & 0.697 & $0.027 *$ \\
\hline おもちゃっぽいー本物っぽい & 1 & -0.091 & 1.121 & $0.010^{*}$ \\
\hline 機械的な一機械的でない & 1 & -0.242 & 0.758 & $0.034^{*}$ \\
\hline 心地わるいー心地よい & 1 & -0.242 & 0.455 & 0.110 \\
\hline 人間らしくないー人間らしい & 1 & -0.364 & 0.515 & $0.049 *$ \\
\hline 違和感のない - 違和感のある & 1 & 0.606 & -0.455 & $0.021 *$ \\
\hline 生き生きしていないー生き生きした & 1 & -0.152 & 0.455 & 0.240 \\
\hline 親しみやすいー親しみにくい & 1 & 0.030 & -0.697 & 0.090 \\
\hline 重々しいー軽やかな & 1 & -0.121 & -0.091 & 0.950 \\
\hline 飽きのくる一飽きのこない & 1 & -0.212 & 0.818 & $0.023^{*}$ \\
\hline 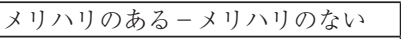 & 2 & 0.667 & -0.455 & $0.012 *$ \\
\hline 元気一杯な - 元気のない & 2 & 0.091 & -0.697 & 0.054 \\
\hline 単調なー複雑な & 2 & 0.303 & 0.970 & 0.130 \\
\hline おもしろいーつまらない & 2 & -0.091 & -0.576 & 0.230 \\
\hline 好きでないー好きな & 2 & -0.061 & 0.636 & 0.091 \\
\hline 印象的でないー印象的な & 2 & 0.091 & 0.364 & 0.500 \\
\hline アアクティブなーアクティブでない & 3 & 0.061 & 0.455 & 0.390 \\
\hline ありふれたーめずらしい & 3 & 0.455 & -0.061 & 0.180 \\
\hline 滑らかな－滑らかでない & 3 & 0.697 & 0.000 & 0.120 \\
\hline
\end{tabular}

となっており, $A_{C}$ のほうが, より自然な, 本物っぽい, 機 械的でない, 人間らしい, 違和感のない, 飽きのこないもの であったといえる．以上の「自然さ・人間らしさ」の因子に 関する分析結果より， $A_{N}$ に比較して $A_{C}$ のほうが，より自然 で人間らしいアニメーションであったといえる.

一方，他の因子に関わる形容詞対については，第二因子に 関わる「メリハリのあるーメリハリのない」のみに有意差があ るといえ， $A_{N}$ に比較して $A_{C}$ のほうが，よりメリハリのある ものであったといえる. このことから, 定常状態と不規則な状

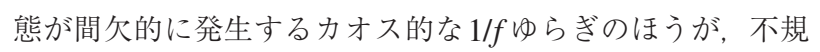
則な状態が続き定常状態になることが無いカオス的でない 1/fゆらぎよりも, よりメリハリのあるゆらぎとして被験者に 評価されたと考えられる。 そして, よりメリハリのあるカオ ス的な $1 / f$ ゆゔのほうが, ゆらぎの効果が高く, $A_{C}$ のほうが より自然で人間らしいアニメーションになったと考えられる。

\section{5. 複数のCGキャラクタによる拍手のアニメーション に関する検討}

\section{1 アニメーションの制作}

4.1 と同様な手法により男性 2 体，女性 2 体の CG キャラク 夕を制作し，それら4体のCGキャラクタからランダムに 1体を選択して髪および服の色をランダムに変更することを 繰り返し，9体のCGキャラクタを生成し，規則的に配置し た，男性のCGキャラクタの肩幅を 1 としたときの配置を 図4 と同様な座標系を用いて図7に示す。また，各 CGキャ ラク夕の拍手の動作に式 (11) 拈よび式 (13) と, 式 (12)の 代わりの次式を用いることにより, CGキャラクタごとに拍 手のタイミングをランダムにずらした。

$$
s\left(t_{n}\right)=\frac{A(n)}{4}\left\{\sin \left(2 \pi \frac{t_{n}+\Delta t}{0.28}-\frac{\pi}{2}\right)+1\right\}
$$
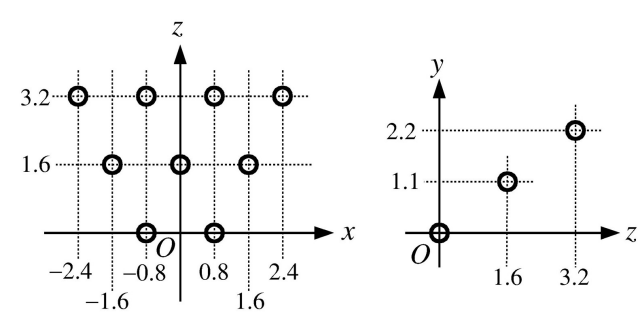

図 7 複数のCGキャラクタの配置 : (a) x-z平面への射影,

(b) $y-z$ 平面への射影.

ここで, $\Delta t(0 \leq \Delta t<0.28)$ は，各 $\mathrm{CG}$ キャラクタごとに異なる 值をとる乱数である。 そして, $D(n)$ に $D_{C}(n)$ を用いて拍手の

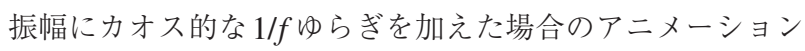
$A_{M F}$ と, 式 (13)に打ける $D(n)$ を 0 とした $1 / f$ ゆらきを加えな い場合のアニメーション $A_{M N}$ を，4.1と同様な手法により制 作した.アニメーションに用いたフレームの例を図8に示す.

\section{2 感性評価実験の方法}

感性評価実験では, 4.2 と同様にして, $A_{M F}$ と $A_{M N}$ の相対 評価をブラインドテストとして実施した。被験者は 19 歳か ら 25 歳までの男女 40 名（約9割が男性）であった。各被験 者に対する実験は次の手順で行った。最初に $A_{M F}$ と $A_{M N}$ を同 時に提示しながら実験に関する説明を行った，次に $A_{M N}$ のみ を提示し, $A_{M N}$ についての感性評価票の各形容詞対について -2から 2 までの評価の欄のいずれかに印を記入させた，次に $A_{M F}$ のみを提示し, $A_{M F}$ についての感性評価票に $A_{M N}$ と同様 に記入させた。最後に $A_{M N}$ および $A_{M F}$ を同時に提示し，任意 の時間, 必要に応じて評価を修正させた。 以上により, 被験 者 1 人あたり 2 通りの感性評価が得られた。

\section{3 感性評価実験の結果およびその分析}

得られた評価に対して，まず，因子分析を 4.3 と同様に適 用した. 固有值 1 以上の次元で因子の数を 2 と決定し, 表 3 に 示す因子負荷量を得た。第1因子においては，「不自然なー自 然な」,「人間らしくないー人間らしい」などに対して因子負 荷量が高く，「自然さ・人間らしさ」に関する因子とした。第 1 因子に関わる形容詞対が「自然さ・人間らしさ」の評価に最 適な形容詞対と考えられ, それらに特に注目することとした。

次に,「自然さ・人間らしさ」の因子に関わる形容詞対に 関して，40名の被験者による評価の平均值，すなわち被験 者間平均值を, $A_{M N}$ と $A_{M F}$ の2通りについて, それぞれ求め

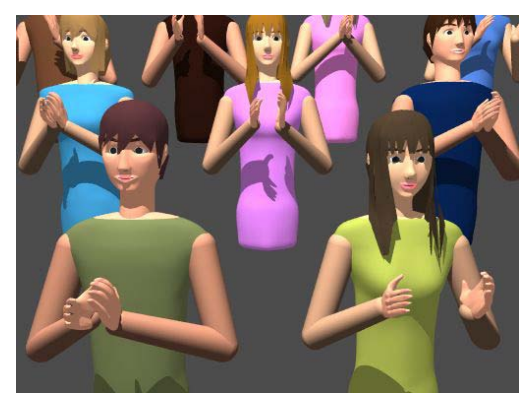

図8 複数のCGキャラクタによるフレームの例. 
表3 因子と因子負荷量.

\begin{tabular}{|c|c|c|c|}
\hline \multirow{2}{*}{$\begin{array}{l}\text { 形容詞対 } \\
\text { (マイナス側のみ) }\end{array}$} & \multirow{2}{*}{ 因 } & \multicolumn{2}{|c|}{ 因子負荷量 } \\
\hline & & 第 1 因子 & 第2因子 \\
\hline 違和感のある & 1 & -0.787 & -0.352 \\
\hline 心地よい & 1 & 0.781 & 0.380 \\
\hline 自然な & 1 & 0.752 & 0.405 \\
\hline 複雑な & 1 & 0.730 & 0.339 \\
\hline 人間らしい & 1 & 0.712 & 0.458 \\
\hline 親しみにくい & 1 & -0.679 & -0.382 \\
\hline 機械的でない & 1 & 0.665 & 0.547 \\
\hline 飽きのこない & 1 & 0.638 & 0.386 \\
\hline 印象的な & 1 & 0.629 & 0.097 \\
\hline 滑らかでない & 1 & -0.601 & -0.357 \\
\hline 生き生きした & 1 & 0.535 & 0.418 \\
\hline アクティブでない & 1 & -0.516 & -0.322 \\
\hline メリハリのない & 1 & -0.428 & -0.151 \\
\hline 軽やかな & 1 & 0.405 & 0.300 \\
\hline めずらしい & 1 & -0.309 & -0.074 \\
\hline 元気のない & 2 & -0.100 & -0.824 \\
\hline つまらない & 2 & -0.294 & -0.647 \\
\hline 本物っぽい & 2 & 0.558 & 0.642 \\
\hline 好きな & 2 & 0.295 & 0.473 \\
\hline \multicolumn{2}{|l|}{ 因子寄与率 } & 0.336 & 0.190 \\
\hline \multicolumn{2}{|l|}{ 累積寄与率 } & 0.336 & 0.527 \\
\hline
\end{tabular}

た. 2 通りの被験者間平均值の間での有意差の有無につい て, t検定を用い, 有意水準を5\%として検定した。表4に, 各形容詞対の被験者間平均值と $p$ 值を示す，検定の結果，15 の形容詞対のなかで 13 の形容詞対において有意差があると いえる，例えば，「不自然な－自然な」に関しては，有意差 があり，被験者間平均值の正負の符号を考慮すると， $A_{M N}$ に 比較して $A_{M F}$ のほうが, より自然なものであったといえる. 同様に, 他の有意差のある形容詞対も考慮すると, $A_{M N}$ に比 較して $A_{M F}$ のほうが, より違和感のない, 心地よい, 自然な, 複雑な, 人間らしい, 親しみやすい, 機械的でない, 飽きの こない, 印象的な, 滑らかな, 生き生きした, アクティブな, メリハリのあるものであったといえる．以上の「自然さ・人 間らしさ」の因子に関する分析結果より， $A_{M N}$ に比較して $A_{M F}$ のほうが, より自然で人間らしいアニメーションであっ たといえる。

\section{6. 結 論}

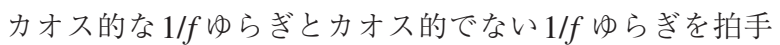
のアニメーションに用いて, 感性評価実験により, どちらが より自然で人間らしい印象を与えるか, 心理的評価に関する 比較検討を行った. カオス的な $1 / f$ ゆらさの発生には 1 次元 変形ベルヌーイ写像による間久性カオスを用い, カオス的で ない $1 / f$ ゆぎは乱数による白色雑音を $1 / f$ 型の周波数特性 を有するディジタルフィルタに通すことにより発生させた。 発生した時系列にスペクトル解析およびカオス性の検定を適 用した結果，2つの時系列の波形は異なるがパワースペクト ルは同じ $1 / f$ 型となることを確認し, また, 相関指数に定性 的な違いがありカオス性の有無を確認した。単一のCGキャ ラクタによる感性評価実験の結果, カオス的でない $1 / f ゆ ら$

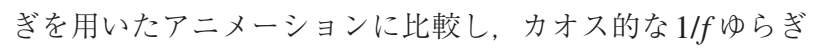

表4「自然さ・人間らしさ」の因子に関する形容詞対に おける被験者間平均値および $p$ 值 (*が付されたものが有意差のある形容詞対).

\begin{tabular}{|c|c|c|c|}
\hline \multirow{2}{*}{$\begin{array}{l}\text { 形容詞対 } \\
\text { (プラス側 - マイナス側 })\end{array}$} & \multicolumn{2}{|c|}{ 被験者間平均値 } & \multirow{2}{*}{$p$ 值 } \\
\hline & $A_{M N}$ & $A_{M F}$ & \\
\hline 違和感のないー違和感のある & -1.100 & 0.600 & $0.000 *$ \\
\hline 心地わるいー心地よい & 0.675 & -0.775 & $0.000 *$ \\
\hline 不自然な－自然な & 0.800 & -0.750 & $0.000^{*}$ \\
\hline 単調なー複雑な & 1.475 & -0.675 & $0.000 *$ \\
\hline 人間らしくないー人間らしい & 1.000 & -0.675 & $0.000 *$ \\
\hline 親しみやすいー親しみにくい & -0.750 & 0.200 & $0.015 *$ \\
\hline 機械的な一機械的でない & 1.225 & -0.400 & $0.000 *$ \\
\hline 飽きのくる一飽きのこない & 0.875 & -0.775 & $0.001 *$ \\
\hline 印象的でないー印象的な & 0.500 & -0.625 & $0.001 *$ \\
\hline 滑らかな－滑らかでない & -0.450 & 0.500 & $0.015 *$ \\
\hline 生き生きしていないー生き生きした & 0.750 & -0.350 & $0.005 *$ \\
\hline アクティブなーアクティブでない & -0.450 & 0.250 & $0.046 *$ \\
\hline メリハリのあるーメリハリのない & -0.450 & 0.550 & $0.012 *$ \\
\hline 重々しいー軽やかな & -0.150 & -0.675 & 0.140 \\
\hline ありふれたーめずらしい & -0.225 & 0.175 & 0.220 \\
\hline
\end{tabular}

を用いたアニメーションのほうが, より自然で人間らしいも のであった。これは，定常状態と不規則な状態が間欠的に発 生するカオス的な $1 / f$ ゆぎのほうが，不規則な状態が続き 定常状態になることが無いカオス的でない $1 / f$ ゆざより も, よりメリハリのあるゆらぎとして被験者に評価され，ゆ らぎの効果が高く，より自然で人間らしいアニメーションに

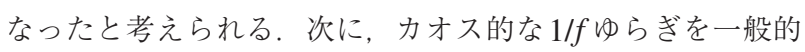
なアニメーションと同様な複数の $\mathrm{CG}$ キャラクタによる拍手 のアニメーションに用いて, $1 / f$ ゆざを用いないアニメー ションと感性評価実験により心理的評価に関する比較検討を 行った。 その結果, $1 / f$ ゆざを用いないアニメーションに 比べ, カオス的な $1 / f$ ゆらきを用いたアニメーションのほう が，より自然で人間らしいものとなったことから，カオス的 な $1 / f ゆ ら き ゙ の$ 有効性を確認した。

\section{参 考 文 献}

[1] Musha, T., Katsurai, K., and Teramachi, Y.: Fluctuations of human tapping intervals, IEEE Trans. Biomed. Eng., BME-32, pp.578-582, 1985.

[2] Yoshinaga, H., Miyazima, S., and Mitake, S.: Fluctuation of biological rhythm in fnger tapping, Physica A, 280, pp.582-586, 2000.

[3] Dotov, D. G., Nie, L., and Chemero, A.: A demonstration of the transition from ready-to-hand to unready-to-hand, PLoS ONE (www.plosone.org), 5, Issue 3, pp.2-9, 2010.

[4] 山田光宏, 佐藤康二, 麻生明義: $1 / f^{\beta}$ ゆらぎを用いた拍手 のアニメーションに関する研究, 芸術科学会論文誌, 9, 4, pp.154-162, 2010.

[5] Tolani, D., Goswami, A., Badler, N. I.: Realtime inverse kinematics techniques for anthropomorphic limbs, Graphical Models, 62, pp.353-388, 2000. 
［6］樋口知之：時系列のフラクタル解析, 統計数理, 37,2 , pp.209-232, 1989.

[7] Grassberger, P. and Procaccia, I.: Measuring the strangeness of strange attractors, Physica D, 9, Issues 1-2, pp.189-208, 1983.

[8］宮野尚哉：非線形時系列解析によるカオス性検定, 数理解 析研究所講究録, 1136, pp.28-36, 2000.

[9］合原一幸, 五百旗頭正：カオス応用システム, 朝倉書店, pp.83-88, 1995.

[10］中村達郎, 今野紀子, 島田尊正, 宮保憲治：1/fゆらぎを 適用した癒し環境空間の検討, 電子情報通信学会通信ソサ イエテイ大会, BS-12-6, 2007.

[11] 井上裕貴, 大和田祥平, 野月悠平, 山田光宏 : 発生方法の 異なる $1 / f$ ゆらきを用いた拍手のアニメーションに関する 研究，第27回 NICOGRAPH論文コンテスト，P01，2011.

[12] 山田光宏, 井上裕貴, 野月悠平, 大和田祥平, 金沢文恵, 中村雅人：カオス性の異なる $1 / f$ ゆらぎを用いた拍手のア ニメーションの感性評価, 第 14 回日本感性工学会大会, E3-2, 2012.

[13] 青木政勝, 新谷幹夫, 筒口拳 : 力学シミュレーションによ る 2 次元アニメーションの自動生成, 電子情報通信学会論 文誌，J84-D-II，9，pp.2040-2047， 2001.

[14］栗山繁, 栗原芳己, 金子豊久：神経振動子を用いた歩行ア ニメーションの自動生成, 電子情報通信学会論文誌, J84D-II, 11, pp.2427-2436, 2001.

[15］工藤俊亮, 幸村环, 池内克史 : 全身を用いたバランス保持 動作のモデル化とその生成, 電子情報通信学会論文誌, J88-D-II, 8, pp.1583-1591，2005.

[16] 安久正紘, 寺町康昌, 山中一雄, 住谷正夫：ゆらぎ現象の 工学的応用について, 応用物理, 61, 7, pp.690-697, 1992.

[17] Ota, S., Fujimoto, T., Tamura, M., Muraoka, K., Fujita, K., and Chiba, $\mathrm{N} .: 1 / f^{\beta}$ noise-based real-time animation of trees swaying in wind fields, Proceedings of the Computer Graphics International, pp.52-59, 2003.

[18］高橋孝彰, 藤本忠博, 千葉則茂: 滝のノイズベースアニ メーション, 芸術科学会論文誌, 4, 2, pp.68-76, 2005.

[19] 大㴊栄作：1/fノイズ・ゆらぎを用いた実写と CGの合成, 映像情報メディア学会誌, 56, 10, pp.1629-1632, 2002.

[20］鈴木慎一, 小林祐司, 姫野由香, 佐藤誠治：ゆらぎ理論と CGシミュレーションによる街路樹の植樹間隔の快適性評 価に関する研究, 日本建築学会技術報告集, 14, 27 , pp.275-280, 2008.

[21］西村竜一, 宮里勉：仮想的集団による拍手音の合成, 電子情 報通信学会技術研究報告, MVE98-100, pp.17-24, 1999.

[22] Aizawa, Y., Kohyama, T.: Asymptotically non-stationary chaos, Prog. Theor. Phys., 71, 4, pp.847-850, 1984.

[23] Kasdin, N. J.: Discrete simulation of colored noise and stochastic processes and $1 / f^{\alpha}$ power law noise generation, Proceedings of the IEEE, 83, 5, pp.802-827, 1995.
[24] 高安秀樹：フラクタル科学, 朝倉書店, pp.88-98, 1987 .

[25] http://www.povray.org

[26] 河内まき子, 丸持正明：2005 AIST 人体寸法データベース, 産業技術総合研究所 H16PRO 287.

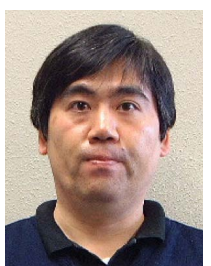

\section{山田 光宏 (正会員)}

1995 年 静岡大学大学院電子科学研究科博士 課程電子応用工学専攻修了. 博士 (工学). 現在, 茨城大学講師. $1 / f$ ゆらぎの応用に関 する研究に従事. 日本感性工学会, 電子情報 通信学会, 芸術科学会, IEEE, 他会員.

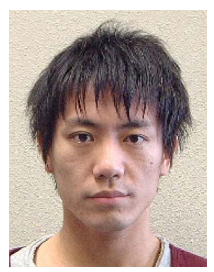

\section{井上 裕貴 (非会員)}

2012年 茨城大学大学院理工学研究科博士前 期課程メディア通信工学専攻修了. 同年, (株) 日立ケーイーシステムズ入社. 在学中は 1/fゆらぎのアニメーションへの応用に関す る研究に従事。

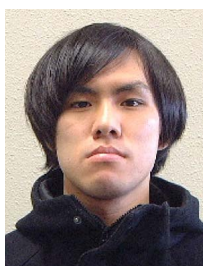

\section{野月 悠平 (非会員)}

2011 年 茨城大学工学部メディア通信工学科 卒業. 在学中, $1 / f$ ゆゔのアニメーション への応用に関する研究に従事.

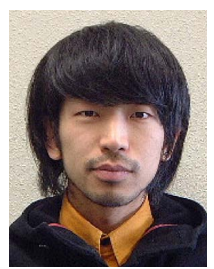

\section{大和田 祥平 (非会員)}

2011年 茨城大学工学部メディア通信工学科 卒業. 在学中, $1 / f$ ゆざのアニメーション への応用に関する研究に従事.

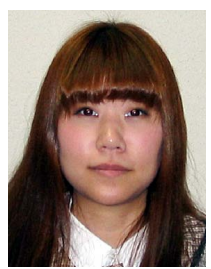

金沢 文惠 (非会員)

2012年 茨城大学工学部メディア通信工学科 卒業. 同年, (株) シーエスデー入社. 在学中,

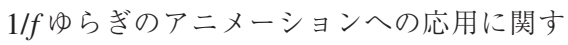
る研究に従事.

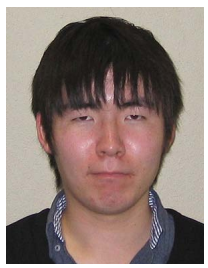

中村 雅人 (非会員)

2012年 茨城大学工学部メディア通信工学科 卒業. 同年, JA常総ひかり入社. 在学中, 1/fゆらぎのアニメーションへの応用に関す る研究に従事。 